\title{
Street Names through Sociological Lenses. Part I: Functionalism and Conflict Theory
}

\author{
Mihai Stelian Rusu ${ }^{1 *}$
}

${ }^{1}$ Lucian Blaga University of Sibiu, Department of Social Work, Journalism, Public Relations, and Sociology, 2A Lucian Blaga, 550169 Sibiu, Romania.

KEYWORDS

Sociology of street names

Politics of memory

Political toponymy

Social theory

Political geography

\begin{abstract}
Street names are mundane spatial markers that besides providing a sense of orientation inscribe onto the landscape the ideological ethos and political symbols of hegemonic discourses. This review article takes stock of the existing scholarship done on the politics of street naming practices in human (political, cultural, and social) geography and rethinks these insights from sociological perspectives. Drawing on Randall Collins' taxonomy of sociological theory, the paper interprets urban street nomenclatures along functionalist, conflictualist, constructionist, and utilitarian lines. The analysis is delivered in two installments: Part I addresses urban nomenclatures from functionalist and conflictualist perspectives, while Part II (published in the next issue of this journal) approaches street names as social constructions and examines their utilitarian value. In doing so, the paper advances the argument that urban namescapes in general and street names in particular should make an important object of sociological reflection and empirical analysis. It is one of the key arguments developed in this paper that toponymy encapsulates broader and intersecting issues of power, memory, identity, language, and space which can be rendered visible through sociological analysis.
\end{abstract}

\footnotetext{
* Contact address: mihai.rusu@ulbsibiu.ro (M. S. Rusu)
} 


\section{"What's in a name?": Sociology's missing answer}

William Shakespeare's wondering - "What's in a name?" - did not intrigue philosophers and social thinkers as much as his more famous ontological question pondered by Hamlet as he struggles with death and immortality ("To be or not to be"). Indeed, the latter turned out to be "the question" that captured the imagination of philosophers (Wilson 2018). His other, nominal question uttered by Juliet has largely failed to stir the "sociological imagination" and thus did little to stimulate empirical research in this particular field of study (Wright Mills 1959). Instead, a solid body of scholarship articulated within the disciplinary bounds of human geography, where, in the last decades, scholars working at the intersection of language, power, and space have developed a thriving field of study under the header of "critical toponymies."

The interdisciplinary character of research done in critical toponymies can hardly conceal its anchoring in the territory of human (political, social, and cultural) geography. While a paradigmatic consensus was being constructed and reinforced through the publication of collected papers that brought together the key scholarly pieces which shaped the field of critical toponymies, the theoretical agenda was being established in human geography's flagship journals. Collections of essays such as those edited by Jani Vuolteenaho and Lawrence D. Berg (1999) under the title Critical Toponymies: The Contested Politics of Place Naming and by Reuben RoseRedwood, Derek Alderman and Maoz Azaryahu (2018a), The Political Life of Urban Streetscapes: Naming, Politics, and Place set up a theoretical framework and defined a specific approach in the study of place-names. Other scholarly pieces, such as Reuben Rose-Redwood, Derek Alderman and Maoz Azaryahu (2010) article "Geographies of Toponymic Inscription" published in Progress in Human Geography and Reuben Rose-Redwood and Derek Alderman's (2011) "Critical Interventions in Political Toponymy" appeared in ACME: An International Journal for Critical Geographies have indicated new directions in critical place-name studies. 
In this paper, I set out to take Shakespeare's nominal question seriously and ask, after reframing the question along more specific lines that will invite an answer from a sociological perspective, "what's in a street name?" In the following sections of this paper, I draw on sociology's intellectual traditions of conceiving the social world and engage them in making theoretical sense of street names as objects of sociological reflection. First, I start by describing sociology's multi-paradigmatic outlook as one of the discipline's defining features and chart its theoretical diversity as clustered into four intellectual traditions (functionalism, conflictualism, constructionism, and utilitarianism). Next, I employ each of these paradigmatic frameworks elaborated in sociological thought to conceive of street names as a subjectmatter of sociological inquiry. Part I discusses street names from functionalist and conflictualist perspectives, while Part II of this series will approach urban nomenclatures from constructionist and utilitarianist theoretical standpoints. Along the process, I will engage with theoretical perspectives already developed within the field of critical toponymies and organize these various strands of thought in terms of sociology's intellectual traditions.

\section{Four sociological traditions: A multi-paradigmatic discipline}

Few things can be said about sociology without running the risk of doing violence to its intricate complexities. Within this scarcity of characterizations that do not require endless contextualization lies the assertion that sociology is a multi-paradigmatic intellectual enterprise (Ritzer 1975). Its disciplinary identity is configured at the intersection of the various forms in which sociology has been imagined and practiced. Auguste Comte's epistemological fantasy of sociology as the queen science standing atop of the hierarchical edifice of all positive sciences (Comte 2009 :35) [1848] was countered by the postmodernist idea that radically questioned sociology's alleged scientific basis and deconstructed the latter as nothing more than a self-serving illusion employed to legitimize its epistemic status (Seidman 1991; Iluț and Rusu 2013). 
In between these extremes, sociology has been conceived in various ways: for some, sociology represents "the" social science par excellence, a kind of meta-discipline that systematizes and integrates the partial perspectives specific to other social sciences (social and cultural anthropology, social history, geography, political science, etc.). Others have relegated it to the status of prima inter pares within the system of social sciences, while some conferred it the unprivileged position of epistemic equality in relation with other social disciplines. Irrespective of how it was imagined, sociology has become tantamount to theoretical pluralism (Rusu 2012). The multi-paradigmatic character is ingrained in sociology's theoretical fabric, where a kaleidoscope of theories of the social world prevails. The same is true for the discipline's methodological approaches, where the trenches in the qualitative-quantitative "paradigm wars" are being continually reinforced and multiplicated by the ongoing confrontations between warring "epistemic tribes" (Bryman 2008).

Different handbooks on sociological theories have come up with widely diverse solutions to the conundrum of classifying two centuries of modern sociological thought in meaningful categories. In this regard, Ruth A. Wallace and Alison Wolf (2006) in their latest edition of Contemporary Sociological Theory: Expanding the Classical Tradition organize the material in six major perspectives: a) functionalism, b) conflict theory, c) evolutionist perspectives, d) symbolic interaction, e) phenomenology, and f) rational choice theories. A simpler and more elegant solution was reached by Randall Collins (1994), who conceives of the historical development of sociological thought as clustered in four intellectual traditions: a) the Durkheimian tradition derived from Émile Durkheim's functionalist view of society as a homeostatic social system whose equilibrium depends on the fulfillment of several key requisites (e.g., value-normative integration and the social control of deviant behavior); b) the conflict tradition founded upon the works of Karl Marx and, to some extent, Max Weber, where society is seen as an arena of conflict and a realm of power struggles fought between collective social actors endowed with opposing interests, which shape a stratified social order characterized by 
inequality and domination; c) the micro-interactionist tradition which develops George Herbert Mead and Herbert Blumer's symbolic interactionism, Alfred Schutz's phenomenological sociology, and Erving Goffman's dramaturgical perspective. In all its variants, micro-interactionist sociology is focused on understanding the social construction of an intersubjectively meaningful social world; and d) the rational/utilitarian tradition builds on contract theories of society and imagines social order as a market regulated by transactions enacted by calculative rational agents in pursuit to maximize their personal utility.

It is along these taxonomic lines drew by Randall Collins that I will organize this sociological analysis of street names. However, for the sake of symmetry, I will relabel sociology's major traditions as functionalism (instead of the Durkheimian tradition), conflictualism (instead of the conflict tradition), constructionism (instead of the micro-interactionist tradition), and utilitarianism (instead of the rational/utilitarian tradition). For the remainder of this paper, which constitutes the first part of a two-part series, I will engage street names and urban nomenclatures through functionalism and conflict theory. The other theoretical frameworks (social constructionism and utilitarianism) will be employed to making sociological sense of street names in the forthcoming, second part of this series.

\section{Functionalism: Street names as pragmatic means of spatial organization}

Functionalist conceptions are predicated upon the premise that society is a social system made up of interrelated parts that work closely together towards reaching a state of structural equilibrium (homeostasis). The biological analogy of society with a living organism is used to underscore that both forms of life (organic and social alike) are made possible by the fulfillment of some vital functions, either by some specialized organs or by their social counterpart, that is, social institutions. The functionalist paradigm has its origins in the social thought espoused by Auguste Comte and was further developed in the sociology of Émile Durkheim and Herbert Spencer, 
as well as in anthropology by Bronisław Malinowski, among others important proponents of functional analysis in the social sciences. Starting with the articulation of Talcott Parsons' structural-functionalism (Parsons 1951), the "functional analysis" of social phenomena has become the standard analytical model in sociology and across the social sciences (although it was not spared of relentless criticism, see Dahrendorf 1958; Wright Mills 1959; Gouldner 1970). The notion of "function" refers to the intended consequences (manifest function) and unintended outcomes (latent function) of social action and phenomena that contribute to the integration of the social system and to maintaining its equilibrium. In contrast, "dysfunctions" are those consequences of social actions that disturb the state of equilibrium and disintegrate the social system (Merton 1968).

Scholars who pioneered the study of street names have resorted from the onset of their endeavor, albeit in a rather clandestine fashion, to the basic scheme of functional analysis. In this regard, Priscilla Parkhurst Ferguson (1988) has pointed out in one of the first studies that have critically explored the political implications of urban toponymy that street names are "not only signs to the city", they "are very much signs of the city" (emphasis in original, p. 386). Her insight on the dual functionality of urban nomenclature was made explicit by Maoz Azaryahu, who repeatedly insisted upon the distinction between the primary, pragmatic function of street names as designating entities facilitating orientation within a system of spatial reference and their second, symbolic function as semiotic devices (Azaryahu 1990; 1996; 1997). Above all, street names perform a basic function of practical value meant "to distinguish between different streets, to provide the users of the city with spatial orientation, and to regulate administrative control over the city" (Azaryahu 1996: 312).

There is thus a triptych of specific aspects that are subsumed by this generic pragmatic function. First, a sub-function consisting of street individualization can be discerned: each urban artery must be named with a unique nominal identifier, devised to differentiate it from all the rest. Such individualization of urban units within the landscape constitutes the 
prerequisite for the efficient fulfillment of the other two functions, that of spatial orientation and administrative control. This principle of rational organization of space, which assumes that each street is labeled differently from all other, has been nevertheless deliberately transgressed out of ideological reasons. Such was the case in postwar Bucharest after the communist authorities started to govern Romania's capital city. In the first year after the abolishment of the monarchy and the declaration of the Romanian People's Republic (R.P.R.) on 30 December 1947, more than 150 street were renamed, in a "global nominatory reform" carried out systematically with the intention of Sovietizing Bucharest's urban toponymy (Ferguson 1988: 391; Light, Suditu, and Nicolae 2002: 137). Besides replacing the royal symbols and figures associated with the defunct monarchic regime with the socialist political iconography (e.g., Piața Carol I honoring Romania's first king became Piața Republicii/Republic Square, while Piața Ferdinand I was renamed into Piața 23 August), another strategy adopted to amplify the ideological impact of the new regime consisted in the multiplication of several names with powerful political resonance across different streets. In this regard, the date of 23 August - commemorating the coup d'etat of 1944 which removed from power the ally of central powers, Marshall Ion Antonescu, and thus set the ground for the communist seizure of governmental power - was assigned not only to the square bearing the name of Romania's second king, Ferdinand I. Overall, 23 August was attributed to ten of Bucharest's streets, on par with the name of I. C. Frimu (1871-1919), a worker activist celebrated as a martyr of the communist movement (Light, Suditu, and Nicolae 2002: 141; on the Romanian communist regime's cult of its pantheon of martyr-workers, see Boia 2001: 217).

Second, and closely related to the principle of street individualization is the street names' function of spatial orientation. This is designed to ensure people's efficient navigation through the urban space as well as to facilitate the circulation of goods and other flowing forms of capital. The practice of toponymic multiplication instituted for politicizing the urban landscape with the symbols of communist power described above had undoubtedly 
generated bewilderment and disorientation among Bucharesters, who were encountering the very same street names in different parts of the city. The peak of this toponymic over-inscription with political symbols - as well as of the local inhabitants' perplexity - was reached in the 23 August raion (one of the capital city's six districts), where in 1954 there were no less than three streets and a square named after the same historical event (Light, Suditu, and Nicolae 2002: 141).

Shifting the perspective from the local residents' standpoint to the holders of power, street names enable the function of administrative control to be exercised by political authorities over the urban landscape (Azaryahu 1996: 312). The normative regulation of urban space has to be understood as indissociable from the wider process of rationalization theorized by Max Weber as specific to modernity (Weber 1930) [1905]. "The disenchantment of the world" through rationalization had brought about not only secularization at the level of religious beliefs and practices, but also the ordering of space along with its scientific management. Starting with the $17^{\text {th }}$ century, in the context of modernization, political authorities had begun articulating "regimes of spatial inscription" and proceeded to the "geo-coding of the world" (Rose-Redwood 2006). The body of scholarship that charted these processes found inspiration in Michel Foucault's seminal thoughts on "governmentality" (Foucault 2007) [1978]. To be sure, I am entirely aware that Foucault's ideas, as well as Weber's, cannot be subsumed under the functionalist paradigm. Foucault's work defies conventional disciplinary delimitations within the academia and is, by his own admission, notoriously difficult to categorize. However, taking into account that the pragmatic function of street names as toponymic inscriptions designed to regulate space is rendered visible through the theoretical lenses polished by the concept of governmentality, I have opted to discuss these ideas under this section as opposed to that dedicated to conflict theory, where the French thinker's conceptualizations could be more adequately classified.

Foucault argues that starting with the $18^{\text {th }}$ century, state formations developed an institutional apparatus endowed with a series of "technologies 
of power" fed by various devices of knowledge production whose application resulted in the disciplinarization of western societies. Statistics and censustaking constitute prime examples of such technologies of government which were instrumental in the exercise of what Foucault has called "biopower" or the political power applied over the population understood as a social body. With regards to the administration of the territory, theorists of space have worked out the concept of "geo-power," characterized by the understanding of "geographical knowledge not as an innocent body of knowledge and learning but as an ensemble of technologies of power concerned with the governmental production and management of territorial space" (Tuathail 1996: 7). The geo-coding technologies of power employed to construct a regime of spatial inscriptions intended to rationalize space consisted of the cartographic and cadastral mapping of the landscape coupled with the development of addressing systems. The latter implied postal coding, house numbering, and street naming which could be conceived, along Foucauldian lines, as political technologies expressed through practices of spatial governmentality employed in the "production of calculable space" (RoseRedwood 2008; 2012).

As a technology of spatial individualization, numbering the houses is indissociable from social control and the policing of urban space. Its implementation across European cities during the late 18 th and early 19th century (London, 1765; Paris, 1779; Berlin, 1797; Vienna, 1806) was driven by military, police, and tax administration purposes (Rose-Redwood 2008; Tantner 2009). As Marco Cicchini (2012) has documented in Geneva, the introduction of house numbering in 1782 was a numeral strategy of achieving the Enlightenment ideal of "urban transparency," complementary to the physical means of lighting the streets at night. A numbered cityscape was deemed to create a new "regime of visibility" that would enable officials to "divide, count, identify and classify urban population in order to regulate the spaces of circulation in the modern city" (Cicchini 2012: 614).

However, it was not only the houses and buildings which were numbered starting with the second half of the $18^{\text {th }}$ century. What another 
French philosopher has put it as "the advent of number" (de Certeau 1984) has also extended to street nomenclature. The apex of this process of rationalizing the urban landscape was reached in the United States of America, where the grid city layout with orthogonal streets was paired with numbered streetscapes (Vuolteenaho 2012). As the German sociologist Georg Simmel pointed out in his notes on "space and the social ordering of society" published at the turn of the 20th century, these alphanumerical systems of addressing are the most efficient means of geographical identification and individualization of a location through toponymic inscription (Simmel 2009: 561-562) [1908].

Whereas in the United States numbered urban nomenclatures have become the nominal default, across the European continent numbering the streetscape remained an eccentric practice restricted to some pockets of the urban fabric in a limited number of places (e.g., Mannheim's Quadrate, Sankt Petersburg's Vasileostrovsky district, the planned town of Milton Keynes). Intrigued by this "transatlantic disparity," Jani Vuolteenaho (2012) accounted for the absence of alphanumeric street nomenclatures in European cities in terms of two factors: first, there is a formal-technical symbiosis between numbered street names and gridiron plans which renders the arithmetical organization of urban space much more difficult in European cities characterized by medieval historical centers with crooked and irregular streets. More important was, however, the politico-ideological factor: although its beginnings are to be found in the previous centuries, it was the French Revolution of 1789 that institutionalized the political usage of street names in honorific and commemorative purposes (Ferguson 1988).

Until the end of the 19th century, street names honoring persons, celebrating values, and commemorating historical dates and events have become "a fundamental feature of modern political culture" (Azaryahu 1996: 311). It was during Henri IV's reign (1572-1610) that Paris' streetscape was turned into a canvas for politicization. Pre-modern urban streets bore largely descriptive and functional names (e.g., Main Road, Church Street, Market Square). When non-indicative in nature, pre-modern street names were 
colorful and idiosyncratic, referring to particular events from the town's local history, and thus made sense only to the locals. A paradigm change occurred in 1605, when Henri IV seized control over Paris' namescape in the context of his large-scale projects of urban development and began assigning street names meant to consolidate his rule (e.g., rue Royale in celebration of the monarchy, rue Dauphine after his inheritor to the throne, rue Christine after his second daughter) (Rose-Redwood, Alderman, and Azaryahu 2018b: 9). In 1728, the Lieutenant Général de la Police ordered that every street in Paris is to be inscribed with its official name, a measure that was embraced throughout the continent in the coming decades (1763 in Stockholm 1765 in English towns). It was, however, the French Revolution of 1789 that "took politics onto the streets" literally by initiating a massive program of renamings that set a recurring pattern for the coming centuries (Ferguson 1988: 390).

It was against this background of modernization that the politicization of street nomenclature took place. In contrast to the United States, in the $19^{\text {th }}$ century Europe simmering with nationalism, what counted was not so much the technical imperative of rationalizing space through numerization as the ideological desire to inscribe the urban landscape with the symbols of political power and national identity. "Unavoidably”, concludes Vuolteenaho (2012), "this turn towards street naming as national pedagogy (a predilection for 'street names with a lesson') and the understanding of urban names as the vehicles of nation-building has had its effects on the ill fate of street numbering in Europe" (p. 669). The symbolic function of street names, that of serving as "vehicles of commemoration" and toponymic means of celebrating the socio-political order, had prevailed in European cities in front of the pragmatic function of organizing space. This political primacy of ideological street names did not nullify the struggle of spatial ordering of European cities but intermingled with it. Abbé Grégoire (1750-1831), whose report of 1794 grounded the republican reform of urban nomenclature following the French Revolution, saw in the new street names not only "emblems [...] capable to act on the heart and to heighten patriotism" but useful instruments that would 
also "facilitate the service of the post office, the movement of commerce, the searches of the travelers, and the tax base of each contributor" (Ferguson 1988: 391).

The outcome of this "ideological rationalization" of European urban spaces brought about a structural instability lying at the very core of modern systems of street toponymy. Politicizing the streetscape entailed the successive renaming of urban nomenclature, especially in the aftermath of regime changes, where rebaptizing the streets was conceived of as a "ritual of revolution" (Azaryahu 1997: 489). The flurry of street name changes - one of the most extensively documented phenomena in scholarship done in the field of political toponymy - has further undermined the principle of spatial coherence and transformed the street nomenclature in a miscellaneous collection of names of widely different historical origins. The main metaphor employed to capture this aspect in plastic terms was that of a "palimpsest" (Palonen 2008), which invites us to read the street nomenclature as a "citytext" in which multiple layers of texts overlap. Another metaphorical rendition was done by drawing an analogy between the urban namescape and geology, which sheds light on the city's various toponymic sediments that can be probed through the analytical means of an "ideological stratigraphy" (Dwyer and Alderman 2008).

Regime changes entail massive reconfigurations of urban toponymy, as the legacy of the defunct regime is de-commemorated while the ideological ethos of the new social order is being institutionalized into the landscape. It was in the context of such major power shifts that researchers have pointed out a functional shift occurring with regards to street toponymy. In times of political unrest and regime change, "the all-important function assigned to street names, that of spatial orientation, simply takes a back seat" (Neethling 2016: 148). This functional shift occurred, for instance, in Romanian cities after the communist seizure of power in the aftermath of the Second World War. In the Transylvanian city of Sibiu (formerly Hermannstadt), in a time span of two years (1947-1948), successive waves of toponymic changes completely reshaped the urban namescape, renaming two-thirds of the street 
nomenclature with communist symbols and heroes (Rusu 2019a). Such a massive transformation of urban toponymy must have rendered the city a spatial-nominal maze for most of its residents. To help the bewildered townspeople navigate through the thoroughly renamed landscape, authorities issued a new city guide that documented the changes and presented the new street names alongside the old denominations (Sibiu 1947). In the context of the regime change, of paramount importance for the new communist authorities was clearly the ideologization of the urban namescape. Despite authorities' bid to minimize the confusion, the street names' function of spatial orientation was nevertheless sacrificed on the altar of political ideologization.

The pragmatic importance of this primary, denotative, and referential function of street names for modern urban governance cannot be emphasized enough. Its crucial role becomes particularly evident in those cases where street names, as well as other toponymic inscriptions such as house numbers and unambiguous physical addressing systems, are not in place. Such is the situation in many rapidly urbanized cities across Africa, which are characterized by "non-descript spatial structures" (Njoh 2010: 427). Cities featuring toponymically uninscribed territories, with sporadically named streetscape (if at all) and unnumbered buildings, encounter major logistical problems that undermine the possibility of efficient urban management. Research done on multiple African cities ranging from Cameroon (Njoh 2010) and Ethiopia (Njoh, Fisseha, Goa, and Gebremichael 2020) to South Africa (Coetzee and Cooper 2007) have grouped the negative consequences of nondescript spatial structures along five dimensions: (1) in terms of economic disadvantages, the lack of proper physical addressing systems impedes the circulation of goods and services, with a particular toll on the delivery services; (2) second, a toponymically unmastered territory thwarts authorities' efforts of policing crime, surveillance, and emergency intervention; (3) urban governance is also rendered difficult, affecting the municipality's provision of public utility services such as water and electricity, but also hindered is the municipality's ability to generate revenues 
through taxation of property; (4) from an electoral perspective, the organization of fair democratic elections is undermined if political authorities cannot rely on solid data of the voters' residential addresses; (5) fifth, a toponymically unorganized space hampers social interaction and deters connectivity between people simply because it makes it harder for them to find each other. Moreover, possessing an officially recognized residential address elevates one's social status and empowers city dwellers with the rights of full citizenship.

The symbolic function of urban namescapes has been discussed in one of the most cited works from critical toponymy studies, in which Maoz Azaryahu (1996) highlighted "the power of commemorative street names." Commemorative street names include, besides the obvious historical dates and events, eponymous names as well (that is, anthroponyms or streets named after human beings). The latter can be conceived of as "nominal memorials" that do more than just memorialize in the public space a cultural, political, and historical figure; they simultaneously celebrate the values embedded in the personality after which a street is named (Rusu 2019b). However, the symbolic function of street names cannot be limited to the category of commemorative denominations. Just as symbolically-loaded are the street names that celebrate abstract political values that lack an explicit historical dimension (e.g., Equality Street, Progress Boulevard, Liberty Square). Moreover, geographical names such as Moscow Boulevard (in cities from socialist countries) or Bruxelles Avenue (in the localities belonging to European Union member or aspiring countries) carry out manifest symbolic connotations (Rusu 2019a). 
Table 1. Functional analysis of street names

\begin{tabular}{|c|c|}
\hline Function & Description \\
\hline \multicolumn{2}{|l|}{ Pragmatic } \\
\hline $\begin{array}{l}\text { Street } \\
\text { individualization }\end{array}$ & $\begin{array}{l}\text { Space is nominally organized through labeling } \\
\text { each street unit with a unique name in order to } \\
\text { construct a univocal system of spatial } \\
\text { localization. }\end{array}$ \\
\hline Spatial orientation & $\begin{array}{l}\text { Street names constitute toponymical landmarks } \\
\text { which, together with other signs, symbols, and } \\
\text { instruments (e.g., maps, address directories), } \\
\text { help users navigate with ease and efficiency } \\
\text { through the urban maze. }\end{array}$ \\
\hline $\begin{array}{l}\text { Administrative } \\
\text { control over urban } \\
\text { space }\end{array}$ & $\begin{array}{l}\text { Street names are useful devices for public } \\
\text { authorities in their administrative effort of } \\
\text { organizing the landscape as a premise for an } \\
\text { efficient exercise of state power, social control, } \\
\text { and efficient fiscalization. }\end{array}$ \\
\hline \multicolumn{2}{|r|}{ 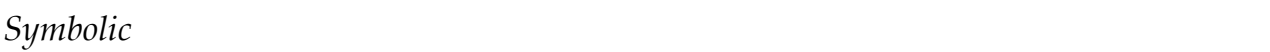 } \\
\hline $\begin{array}{l}\text { Legitimation of the } \\
\text { status quo }\end{array}$ & $\begin{array}{l}\text { When they are invested with political names } \\
\text { (commemorating historical figures and events } \\
\text { or celebrating the ideological ethos of a } \\
\text { particular political regime), street names } \\
\text { become means of legitimizing the current } \\
\text { social order. }\end{array}$ \\
\hline $\begin{array}{l}\text { Political } \\
\text { communication }\end{array}$ & $\begin{array}{l}\text { Street names with ideological content inscribed } \\
\text { onto the urban landscape are political } \\
\text { messages that authorities transmit to the public } \\
\text { they govern and embed into the structures of } \\
\text { everyday life. }\end{array}$ \\
\hline $\begin{array}{l}\text { Construction of } \\
\text { collective identities }\end{array}$ & $\begin{array}{l}\text { Street nomenclature is a means of asserting } \\
\text { identity projects through the urban landscape } \\
\text { (e.g., gender, racial, and ethnic politics), by } \\
\text { which political authorities draw the } \\
\text { boundaries of belonging as well as the borders } \\
\text { of group exclusion. }\end{array}$ \\
\hline
\end{tabular}

Source: Author's elaboration

The body of scholarship that explored the symbolic facets of urban namescapes has made clear that street names are more than useful indicators for spatial orientation. When they convey political messages, commemorate historical events, celebrate certain people, and make reference to ideological 
places, street names are powerful toponymic means of legitimizing the status quo, political communication, and the construction of collective identities (see Table 1). This second, semiotic function of street names consisting in the political construction of a symbolic geography endowed with collective memories and social identities will be addressed at length in the section dedicated to conceiving street names through the theoretical lenses of social constructionism (see the second installment of this two-part series, forthcoming in the next issue of this journal).

\section{Conflictualism: Street names as cultural arenas of power struggle}

The conflict tradition in sociology is indissociable from the towering figure of Karl Marx, whose dialectical materialist view of historical development situated conflict, domination, and power struggles at the core of his understanding of society. Whereas orthodox Marxism is undermined in its explanatory power by the reductionistic conception of social inequalities as determined by essentially economic factors belonging to the material infrastructure of society (Marx 1967) [1887], non-Marxist conflict theories insist upon the importance of cultural factors (belonging to a society's "ideological superstructure") in shaping and reinforcing power relations, patterns of domination, and structures of socio-economic inequalities (Weber 1978; Gramsci 1971; Althusser 1970; Dahrendorf 1959; Bourdieu 1984). Irrespective of their relationship with Marxism - Marx himself notoriously recant from Marxism ("Tout ce que je sais, c'est que je ne suis pas Marxiste") - what they all have in common is an understanding of society as an arena of conflict in which various social groupings driven by divergent material interests struggle against each other for seizing power, exerting domination, and obtaining or maintaining privileges.

When engaged in theorizing street names, conflict theory sees through urban toponymy to uncover signs of memory politics and identity struggles between groups pursuing their antagonistic interests sustained by particular ideological worldviews. We have already learned from the previous section 
that "place names are more than innocent spatial references or passive artefacts" (Alderman and Inwood 2013: 2). Instead, street names are fraught with politics. Researchers working within the conflict tradition are not seduced by a purely semiotic analysis, centered upon decoding the symbolic meanings encrusted in street names. On the contrary, they situate street names' symbolic function as "embedded in social power relations and struggles over the identities of places and people" (p. 2). Therefore, the epistemic stake underpinning this strand of research inspired by sociology's conflict tradition consists in revealing the power relations inscribed within urban toponymy. Such an objective is made possible through an analysis that is less focused on reading street names as textual artifacts and the configuration of urban namescape as "city-text" and much more sensitive to street naming as an intrinsically contentious process.

Scholars of toponymy have drawn on Antonio Gramsci's notion of hegemony in theorizing the politics of street names (Vuolteenaho and Puzey 2018). In his writings, Gramsci (1971) [1929-1935] articulated the idea that the domination exerted by the ruling class in not reducible to economic means; socioeconomic inequality is maintained and reproduced through the exertion of cultural hegemony. This consists of imposing the ruling class's cultural worldview - its belief- and value system - as natural and commonsensical. In his Prison Notes, Gramsci wrote that street names, together with libraries, schools, the mass media, and other cultural institutions, belong to the "ideological structure of the ruling class" by which the powerful succeed in imposing their self-serving worldview as taken for granted by the oppressed segments of society. Besides inspiring place name scholars on working out a Gramscian approach to toponymy (Puzey and Vuolteenaho 2016), Gramsci was also one of the few classical social theorists who analyzed directly the politics of street names. In a piece written in 1917, he criticized as a resident of Turin, Italy the municipality's plan of renaming the city's medieval streetscape with political names (e.g., via dei Carrozzai/Coachmakers' Street into via Domenico Berti, after a politician who died in 1897). Gramsci condemned the "evisceration of the old Turin," where medieval street names 
were organically tied with the historical experience of the community, in which every street name was "the memory of a moment of collective life." The previous, descriptive urban namescape "was like a patrimony of memories, of affection, binding individuals together more strongly with the ties of solidarity through memory"; the new nomenclature not only destroys this organic heritage of the past but also inscribes the public space with the symbols of the "shop-keeping bourgeoisie," and thus reinforces the ruling class' hegemonic domination through cultural and symbolic means (cited in Puzey and Vuolteenaho 2016: 70).

In the remainder of this section, I will discuss street names through the conceptual lenses provided by conflict theory, as politically-contentions toponymic means of exerting cultural hegemony onto public space and urban landscape. From this theoretical standpoint, I will review works that have addressed the politics of street names, naming, and renaming in relation to the categories of race, ethnicity, colonialism, religion, and gender.

Derek Alderman (2002), the main proponent of conceiving street names as cultural and memorial arenas, has explored in a series of studies "place naming as a mechanism of spatial (in)justice." Focused on the politics of commemoration around the slain leader of the civil right movement in the America, Martin Luther King Jr. (1929-1968), his works have charted the racial lines of demarcation drawn through assigning street names and the confrontations between Whites and Afro-Americans over their redefinition and/or maintenance (Alderman and Inwood 2013). Most often, the bone of contention is not direct opposition towards naming a street after Martin Luther King Jr., but the location of the street bearing his name. The wider semantics of attributing such a street name also indicates a hermeneutical fault-line between the two sides, which embrace widely divergent interpretations. Activists campaigning for the memorialization of King Jr. in urban toponymy argue that the street chosen for this purpose must be important enough in the city's road network, and this is a crucial requirement since the ultimate aim is to transcend the boundaries of residential segregation. Instead, opponents wish to limit the slain leader's 
commemoration to the neighborhoods inhabited by Afro-Americans and express their fear of the street thus named to be associated with the stereotypical image of poverty and crime, which will allegedly devalue their properties. The opponents' strategy, that of imposing "scalar limits" through which to restrict activists' toponymic project to the peripheral areas of the city, produces the perverse effect of reproducing racial segregation. To maintain these racial borders intact, opponents resorted to a "policing of scale in which certain activities by African Americans are allowed in certain places as long as they are not scaled beyond the black community and disrupt segregated space" (Alderman and Inwood 2013: 11).

Racial politics of toponymy can also overlap with neoliberal agendas regarding street names. In 2013, in response to protests from the AfroAmerican community, the city council of Tulsa, Oklahoma voted to "rename" a street honoring a white supremacist. The Brady Street, previously named after Tate Brady (1870-1925) - a Ku Klux Klan member who was involved in the 1921 Tulsa race massacre - was "renamed" after Mathew B. Brady, a 19th century American photographer who has documented the Civil War. Resorting to this simulacrum of change and racial justice, the city officials engaged in

a neoliberal name game, a strategic manipulation of Tulsa's geography of names, signs, and memories. City leaders appropriated and exploited the forms, meanings and ambiguities of the toponymic landscape and sanitized the Brady name itself to ensure the least disruptive impact on the financial interests, addresses, and place branding of white business owners on the road, many of whom wanted the street's name and memory left alone (Brasher, Alderman, and Subanthore 2018: 3).

Besides charting the "white privilege" and the toponymic practices of contesting this form of racializing the public space, researchers have studied street names in the light of ethnic relations in a variety of political contexts. In this regard, a recent paper has captured the ethnopolitics played out at the level of Sibiu's urban toponymy in Romania during the last two centuries (Rusu 2019a). In the second half of the long 19th century, as part of the broader process of politicizing space and the urban landscape, the city's Saxon authorities have renamed several of the older street names after prominent 
local and imperial personalities (e.g., former mayors and Joseph II, 1741-1790, ruler of the Habsburg Empire to which the city belonged). This Saxonization of the local namescape has been re-ethnicized through a Romanianization of the city after Transylvania became part of Romania following the First World War. The end of the Second World War had brought in power the new communist regime and, as a consequence, the Soviet colonization of urban nomenclature took place, which implied a thorough Russification of the city's namescape. After Romania distanced itself from the Soviet Union and the country re-appropriated the national ideology starting with the mid-1960s, Sibiu's streetscape experienced a second toponymical Romanianization, a process that continues to unfold following the demise of the communist order in 1989. Similar ethnopolitics of street names have occurred in other multiethnic cities from Transylvania (Rusu 2020a) as well as across the Central and Eastern Europe (Chloupek 2019).

Colonialism, decolonization, and post-colonialism have also provided geopolitical contexts for toponymic struggles to emerge. During the long history of colonial rule, European powers have impressed their ideological mark upon the localities embedded within the expanding bounds of their empires. Due to its strategic location, Dakar was France's "chief lieux de colonisation in West Africa" (Bigon 2009). Under Napoleon III (1808-1873), the Second French Empire officially occupied Dakar in 1857 and the place became subject of colonial urban planning. As part of the development of the city, the French authorities have attributed names to the urban landscape. An analysis of this colonialized namescape revealed that most of the street names were related to "individuals who had played significant roles in the effective colonization of Senegal" and sub-Saharan Africa, such as military and navy officers, governors, engineers, and explorers (Bigon 2009: 441). The same toponymic story was repeated in Singapore, where the British Empire baptized the street nomenclature after European colonial administrators, councilors, and governors, the British royalty and war heroes, and idyllic images of the English countryside (Yeoh 1992; 1996). 
Such colonialist inscriptions of power are not bound to the past. In 2003, soon after invading Iraq, the occupying US Army renamed the Saddam International Airport into Baghdad International Airport. To facilitate its management of space, the military has Americanized Baghdad's main arteries by renaming them as "California Street," "Virginia Avenue," and "Route Irish" (Rose-Redwood, Alderman, and Azaryahu 2010: 454). However, in contrast to the 19th century colonialist practices employed by European imperial powers in cities like Dakar and Singapore, the US army reworked unofficially the toponymic map of Baghdad for military, operational purposes. Nevertheless, what this case in point suggests is the colonialist proclivity to seize control of the occupied territory by imposing the ruler's own toponymy over the captured landscape.

Postwar decolonization and the dissolution of European empires against the resurgence of "third world" nationalisms brought about the deconstruction of colonial toponymies. In Singapore, for instance, the independence gained from the British empire in 1965 translated into the rewriting of the city's street namescape. The process of "'Malayanizing' the colonial landscape" was pursued through inscribing nationhood and symbols of local identity in the toponymy (Yeoh 1996: 301). These changes evoked the toponymic transformations that occurred in Nairobi, Kenya which became independent in 1963. Just as in Singapore and other decolonized places, colonial street names were replaced with the symbols of nationalism. The purging of colonial nomenclature and its replacement with national references rendered street names into "sites for restitution of justice" but also in cultural arenas for the spatialization of local memory and ethnic representation (Wangui Wanjiru and Matsubara 2016: 1).

Recently, in the context of the worldwide protests against racial discrimination triggered by the police killing of George Floyd in Minneapolis, USA, activists in Glasgow, Scotland have installed alternative street names plates below the official ones honoring former slave owners. For instance, Wilson Street was retitled as Rosa Park Street (in honor of the heroine of the civil rights movement), while Buchanan Street (named so after one of 
Glasgow's 18 th century "tobacco lords") was alternatively renamed as George Floyd Street (Sullivan 2020). As activists were contesting Glasgow's street nomenclature, protesters in Bristol, England have toppled the bronze statue of slave trader Edward Colston and thrown it into the water (Siddique and Skopeliti 2020). Pockets of conservative resistance also exist: the University of Oxford's Oriel College has restated its refusal to remove the statue of Cecil Rhodes, a 19th century British magnate and colonial governor in South Africa (Race and Briant 2020). In London, the mayor Sadiq Khan ordered a review of the capital's statues, plaques, and street names in a bid to ensure that the monuments reflect the city's diversity (Ng 2020), while across the United States there are ongoing struggles to remove the confederate monuments from public space. The dual targeting of statues and street names is not arbitrary, as both of them are spatial materializations of the past, "sites of memory" in Pierre Nora's terms (Nora 1989 - lieux de mémoire). Whereas statues are history cast in bronze or carved in stone, street names are textual memorials and the literal spelling out of history into the public landscape.

Closely related to ethnicity and colonialism, another constitutive dimension of the power struggles fought in renaming the space is religious identity. In this regard, Saul B. Cohen and Nurit Kliot (1992) have shown how the territory occupied by Israel following the Six Days War of 1967 was toponymically colonized through Biblical/Talmudic and nationalist/Zionist names which replaced the older Arabic denomination. What this example shows is the intricate entanglements of nationalism, ethnicity, and religion that come together in shaping powerful nominative regimes employed in the political appropriation of space.

Not least, gender constitutes yet another crucial factor in structuring socio-geographic inequalities and power differentials. Studies that have addressed the issue of gender in urban toponymy have documented the "masculine domination" theorized by Pierre Bourdieu (2001) manifested over space as well. Contesting the patriarchal regime of spatiality, feminist geographers have based their critique on the idea that "space and place [...] are gendered through and through" (Massey 1994: 186). The sexual division 
of space into the public sphere and the domestic realm legitimizes the masculine domination upon the former and relegates women in the latter. Women's exclusion from urban street nomenclature is thus underpinned by this gendered patterning of space into a masculine public sphere and a feminine private realm (McDowell 1999).

Empirical studies conducted in multiple urban sites substantiate the gender imparity underpinning public space expressed in the toponymic masculinization of street names. In Paris, only 2.6 percent of the street nomenclature is named after women, while on France's entire territory, the proportion falls to two percent. The percentage of feminine presence increases to 7.70 percent in Paris, and 5.97 for France, if we consider it in relation to anthroponyms, that is, the total of streets named after people (Jaffe 2015). This pattern is present in other European capital cities as well, where females represent well under ten percent of the street nomenclatures honoring people (6.06\% in Bucharest, 7.70\% in Rome, 8.24\% in Vienna) (see Table 2). Of the capital cities for which statistical data are available, it is only in Warsaw that women's presence in the urban street nomenclature transcends the threshold of ten percent (11.78\%) (Walkowiak 2018). A notable exception in this regard is found in Hamburg, where women are close to 15 percent. Overall, in the sample of European cities included in this analysis, which is based on a collection of almost 50,000 streets, of which over 20,000 are named after people, the streets honoring women represent 8.70 percent of the latter total (see also Rusu 2020b).

The same starking gender differential was further observed in other socio-spatial settings, ranging from Paris' subway (Jaffe 2015) to Romania's educational namescape (Rusu 2019b). Adding offense to injury, many of the females' names inscribed into the streetscape are not celebrated for their own achievements, but as the wives, daughters, and mothers of famous men (Poon 2015; Niculescu-Mizil 2014). This perpetuation of masculine domination even when female names are present in street nomenclature - characterized as "nomination by patriarchal proxy" (Rusu 2019b: 90) - is further enhanced in southern Europe. In this regard, the toponymic condition of women in 
Spanish cities and towns is especially burdening, given the statistical fact that besides the scarcity of female names, "among the women with streets named after them, 83 percent are either saints or representations of the Virgin Mary" (Llaneras and Pérez Colomé 2017).

Table 2. Gender distribution of street names in major European cities

\begin{tabular}{|c|c|c|c|c|c|c|c|}
\hline \multirow[t]{2}{*}{ Place } & \multicolumn{2}{|c|}{ Females } & \multicolumn{2}{|c|}{ Males } & \multicolumn{2}{|c|}{ People } & \multirow{2}{*}{$\begin{array}{c}\text { Total } \\
\text { (including } \\
\text { neutral } \\
\text { names) }\end{array}$} \\
\hline & $N$ & $\%$ & $N$ & $\%$ & $N$ & $\%$ & \\
\hline Bucharest & 96 & 6.06 & 1,487 & 93.94 & 1,583 & 100 & 4,941 \\
\hline Hamburg & 415 & 14.13 & 2,523 & 85.87 & 2,938 & 100 & $\sim 9,000$ \\
\hline Paris & 166 & 7.70 & 1,860 & 91.81 & 2,026 & 100 & $\sim 6,000$ \\
\hline Rome & 580 & 7.11 & 7,575 & 92.89 & 8,155 & 100 & 16,550 \\
\hline Vienna & 361 & 8.24 & 4,018 & 91.76 & 4,379 & 100 & $\sim 6,800$ \\
\hline Warsaw & 159 & 11.78 & 1,191 & 88.22 & 1,350 & 100 & 5,367 \\
\hline Total & 1,777 & 8.70 & 18,654 & 91.30 & 20,431 & 100 & $\sim 48,670$ \\
\hline
\end{tabular}

Source: author's elaboration based on multiple sources

Faced with this pattern of discrimination, various feminist organizations across Europe have initiated campaigns of recognizing women's urban invisibility as well as ways of rendering them visible. For example, in 2015, activists from the organization Osez le féminisme! (Dare feminism!) launched a campaign named Fémicité by which some of Paris' "sexist" street names were renamed after prominent women (e.g., Quai de la Tournelle near the Notre Dame cathedral was re-baptized in Quai Nina Simone, after the American musician and civil rights activist), in what a newspaper called "a feminist stunt" (Gee 2015). Such struggles for gender recognition (Honneth 1995) have started to pay off, with several cities embracing street name policies designed to promote women's presence in the urban namescapes. In this regard, in Paris, a political decision was taken "to favor the names of women in public space" with 75 percent of the new names proposed to the city's naming commission honoring women (Plummer 2017). Valencia has outperformed this Parisian standard of affirmative action in the 
realm of neo-toponymy by ruling that "four out of five newly named streets must bear the names of women" (O'Sullivan 2016).

What these studies grounded in various strands of conflict theory reveal is the multiplicity of inequalities that are written into street names. Power struggles are indeed constitutive to urban namescape, which become symbolic stakes in a variety of racial, gender, ethno-national, and religious confrontations. Scholarship of toponymy informed by conflict theories thus emphasizes the differential power relations embedded into the politics of street naming practices that are responsible for the spatial visibility of the dominant groups and the invisibility of other social categories (females, ethnic and racial minorities, colonized populations, and other subaltern subjects).

\section{Conclusions}

Street names and the urban nomenclatures they are organized into have been largely neglected in sociological scholarship. The most important contributions to articulating an understanding of street names were made by human (political, cultural, and social) geographers, who have drawn of various strands of social theory to explore the multiple facets of urban nomenclature. Besides taking stock of the state of the art in place-names studies, the stake of this review article was to show how street names could be approached sociologically from the four main competing theoretical perspectives existing in this discipline. In this paper, which is the first of the two-parts series, I conceived of street names through sociological perspectives grounded in functionalism and conflict theory.

Toponymic inscriptions through street naming construct linguistic landscapes endowed with dual functions: first, urban nomenclatures are nominal devices of organizing space for the purpose of urban governance, policing the territory and exerting socio-spatial control, and efficient fiscalization (among other administrative purposes). Besides being a spatial technology of governmentality, when ideologized with commemorative, political, and symbolic features, street names function as toponymic means of 
fashioning collective identities. Street names are also vehicles of collective memory and powerful toponymic means of constructing memorial landscapes and geographies of public remembrance. It is to this symbolic function of street names that political authorities resort to legitimize their power by materializing into the landscape a self-serving ideological ethos.

Street names are also fraught with social conflicts and contentious politics. This becomes clear when reading urban street names through conceptual lenses informed by conflict theory. Scholarship done from this theoretical vantage point has shown how urban nomenclatures are structured by power relations and that place-naming is always a (contestable) gesture of power. Place-name studies are littered with empirical papers that emphasized how street names constitute cultural arenas of power struggles between protagonists divided in terms of race, ethnicity, religion, or gender.

In the second part of this contribution, which will be published in the forthcoming issue, I switch sociological theories and address street names through conceptual frameworks anchored in constructionist (social phenomenology) and utilitarianist (rational choice theory) perspectives. Drawing on the metaphor of the "city-text," I will explore the discursive construction of urban namescapes as well as their re-writing through the practices of street renaming. Finally, the paper will examine, from a utilitarian standpoint, the neoliberal commodification of place-names across various scales and geographical scopes. In doing so, I contend that street names constitute important objects of sociological reflection and urge sociologists to join human geographers and other disciplinary breeds of social researchers in engaging seriously with Shakespeare's intriguing onomastic question. 


\section{Acknowledgements}

This work was supported by a grant of the Romanian Ministry of Education and Research, CNCS-UEFISCDI, project number PN-III-P1-1.1-TE-2019-0238, within PNCDI III.

\section{References:}

Alderman, Derek and Joshua Inwood. 2013. "Street Naming and the Politics of Belonging: Spatial Injustices in the Toponymic Commemoration of Martin Luther King Jr". Social \& Cultural Geography 14 (2): 211-233.

Alderman, Derek. 2002. "School Names as Cultural Arenas: The Naming of U.S. Public Schools after Martin Luther King, Jr“. Urban Geography 23 (7): 601-626.

Althusser, Louis. 1970. "Ideology and Ideological State Apparatuses (Notes towards an Investigation)". In Lenin and Philosophy and Other Essays. New York, NY: Monthly Review Press.

Azaryahu, Maoz. 1990. “Renaming the Past: Changes in 'City Text' in Germany and Austria, 1945-1947". History and Memory 2 (2): 32-53.

Azaryahu, Maoz. 1996. "The Power of Commemorative Street Names". Environment and Planning D: Society and Space 14: 311-330.

Azaryahu, Maoz. 1997. "German Reunification and the Politics of Street Names: The Case of East Berlin". Political Geography 16 (6): 479-493.

Bigon, Liora. 2009. “Urban Planning, Colonial Doctrines and Street Naming in French Dakar and British Lagos, c. 1850-1930“. Urban History 36: 426-448.

Boia, Lucian. 2001. History and Myth in Romanian Consciousness. Budapest: Central European University Press.

Bourdieu, Pierre. 1984. Distinction: A Social Critique of the Judgement of Taste. Cambridge, MA: Harvard University Press.

Bourdieu, Pierre. 2001. Masculine Domination. Cambridge: Polity Press.

Brasher, Jordan P. Alderman, Derek H., and Aswin Subanthore. 2018. "Was Tulsa's Brady Street Really Renamed? Racial (In)justice, Memorywork and the Neoliberal Politics of Practicality". Social \& Cultural Geography, DOI: 10.1080/14649365.2018.1550580.

Bryman, Alan. 2008. "The End of the Paradigm Wars? “. In The SAGE Handbook of Social Research Methods, edited by Pertti Alasuutari, 
Leonard Bickman, and Julia Brannen, 12-25. London: SAGE Publications.

Chloupek, Brett R. 2019. "Public Memory and Political Street Names in Košice: Slovakia's Multiethnic Second City". Journal of Historical Geography 64: 25-35.

Cicchini, Marco. 2012. A New "'Inquisition'? Police Reform, Urban Transparency and House Numbering in Eighteenth-Century Geneva“. Urban History 39 (4): 614-623.

Coetzee, Serena and Antony Cooper. 2007. "The Value of Addresses to the Economy, Society and Governance - A South African Perspective“. The $45^{\text {th }}$ Annual Conference of the Urban and Regional Information Systems Association (URISA), 20-23 August 2007, Washington, DC.

Cohen, Saul B. and Nurit Kliot. 1992. "Place-Names in Israel's Ideological Struggle over the Administered Territories". Annals of the Association of American Geographers 82 (4): 653-680.

Collins, Randall. 1994. Four Sociological Traditions. Revised and Enlarged Edition. Oxford: Oxford University Press.

Comte, Auguste. 2009. A General View of Positivism. Cambridge: Cambridge University Press.

Dahrendorf, Ralf. 1958. 'Out of Utopia: Toward a Reorientation of Sociological Analysis'. American Journal of Sociology 64 (2): 115-127.

Dahrendorf, Ralf. 1959. Class and Class Conflict in Industrial Society. Stanford, CA: Stanford University Press.

de Certeau, Michel. 1984. The Practice of Everyday Life. Berkeley, CA: University of California Press.

Dwyer, Owen J. and Derek Alderman. 2008. "Memorial Landscapes: Analytic Questions and Metaphors". GeoJournal 73: 165-178.

Ferguson, Priscilla P. 1988. Reading City Streets. The French Review 61 (3): 386397.

Foucault, Michel. 2007. Security, Territory, Population: Lectures at the Collège de France, 1977-1978. Basingstoke: Palgrave Macmillan.

Gee, Oliver. 2015. "Sexist' Paris Streets Renamed in Feminist Stunt". The Local, 26 August 2015. Available online at https:/ / www.thelocal.fr/20150826/ paris-neighbourhood-gets-afeminist-makeover.

Gouldner, Alvin. 1970. The Coming Crisis of Western Sociology. New York, NY: Basic Books.

Gramsci, Antonio. 1971. Selections from the Prison Notebooks. New York, NY: International Publishers. 
Honneth, Axel. 1995. The Struggle for Recognition: The Moral Grammar of Social Conflicts. Cambridge: Polity Press.

Iluț, Petru and Mihai Stelian Rusu. 2013. "Sociologia postmodernă și capcanele teoretizării haute couture". In In căutare de principii. Epistemologie și metodologie socială aplicată, edited by Petru Iluț, 91-112. Iași: Polirom.

Jaffe, Eric. 2015. "The Streets of Paris, Renamed for Women". CityLab. Available online at https://www.citylab.com/design/2015/08/thestreets-of-paris-renamed-for-women/402526/

Light, Duncan, Suditu, Bogdan, and Ion Nicolae. 2002. "Toponymy and the Communist City: Street Names in Bucharest, 1948-1965“. GeoJournal 56: 135-144.

Llaneras, Kiko and Jordi Pérez Colomé. 2017. “Gender Inequality in Spain's Street Names". El País, 13 January 2017. Available online at https://elpais.com/elpais/2017/01/11/inenglish/1484146810_75748 2.html.

Marx, Karl. 1967. Capital. A Critique of Political Economy. Volume 1: The Process of Capitalist Production. New York, NY: International Publishers.

Massey, Doreen. 1994. Space, Place, and Gender. Minneapolis, MN: University of Minnesota Press.

McDowell, Linda 1999. Gender, Identity and Place: Understanding Feminist Geographies. Minneapolis, MN: University of Minnesota Press.

Merton, Robert K. 1968. Social Theory and Social Structure. Enlarged Edition. New York, NY: The Free Press.

Neethling, Bertie. 2016. "Street Names: A Changing Urban Landscape". In The Oxford Handbook of Names and Naming. Edited by Carole Hough 144157. Oxford: Oxford University Press.

Njoh, Ambe J. 2010. 'Toponymic Inscription, Physical Addressing and the Challenge of Urban Management in an Era of Globalization in Cameroon'. Habitat International 34: 427-435.

Njoh, Ambe J., Fisseha, Samrawit, Goa, Adisu and Dawit Gebremichael. 2020. "Street and Property Identification and the Challenge of Urban Management in Mekelle City, Ethiopia“. Journal of Asian and African Studies. DOI: 10.1177/0021909620926536.

$\mathrm{Ng}$, Kate. 2020. "Sadiq Khan Will Review All Monuments in London to Ensure they Reflect City's Diversity“, Independent, online edition, 9 June 2020, available online at https:/ / www.independent.co.uk/news/uk/home-news/sadiqkhan-statues-london-diversity-edward-colston-black-lives-mattera9555941.html. 
Niculescu-Mizil, Ana-Maria. 2014. “(Re)Naming Streets in Contemporary Bucharest: From Power Distribution to Subjective Biography". Analize: Journal of Gender and Feminist Studies 3: 69-94.

Nora, Pierre. 1989. "Between Memory and History: Les Lieux de Mémoire". Representations 26: 7-24.

O'Sullivan, Feargus. 2016. “The Women Replacing Spain's Franco-Era Street Names". CityLab. Available online at https:/ / www.citylab.com/solutions/2016/11/the-womenreplacing-spains-franco-era-street-names/508478/.

Palonen, Emilia. 2008. "The City-Text in Post-Communist Budapest: Street Names, Memorials, and the Politics of Commemoration". GeoJournal, 73: 219-230.

Parsons, Talcott. 1951. The Social System. New York, NY: The Free Press of Glencoe.

Plummer, William. 2017. "Ce que révèlent les noms des rues de Paris". Le Figaro. Available online at https://www.lefigaro.fr/fig-data/ruesparis/.

Poon, Linda. 2015. "Mapping the Sexism of City Street Names". CityLab. Available online at https:/ / www.citylab.com/ equity/2015/11/mapping-the-sexism-ofcity-street-names/414094/.

Puzey, Guy and Jani Vuolteenaho. 2016. “Developing a Gramscian Approach to Toponymy". In Names and Their Environment: Proceedings of the $25^{\text {th }}$ International Congress on Onomastic Sciences, vol 2, edited by Carole Hough and Daria Izdebska, 66-77. Glasgow: University of Glasgow.

Race, Michael and Nathan Briant. 2000. "Cecil Rhodes: Protesters Demand Oxford Statue Removal". BBC News, online edition, 9 June 2020, available online at https://www.bbc.com/news/uk-englandoxfordshire-52975687.

Ritzer, George. 1975. "Sociology: A Multiple Paradigm Science". The American Sociologist 10 (3): 156-167.

Rose-Redwood, Reuben and Derek Alderman. 2011. "Critical Interventions in Political Toponymy“. ACME: An International Journal for Critical Geographies 10 (1): 1-6.

Rose-Redwood, Reuben, Alderman, Derek and Maoz Azaryahu. 2010. "Geographies of Toponymic Inscription: New Directions in Critical Place-Name Studies“. Progress in Human Geography 34 (4): 453-470.

Rose-Redwood, Reuben, Alderman, Derek and Maoz Azaryahu. (Eds.) 2018a. The Political Life of Urban Streetscapes: Naming, Politics, and Place. London and New York, NY: Routledge. 
Rose-Redwood, Reuben, Alderman, Derek, and Maoz Azaryahu. 2018b. "The Urban Streetscape as Political Cosmos". In The Political Life of Urban Streetscapes: Naming, Politics, and Place, edited by Reuben RoseRedwood, Derek Alderman, and Maoz Azaryahu, 1-24. London and New York, NY: Routledge.

Rose-Redwood, Reuben. 2006. "Governmentality, Geography, and the GeoCoded World“. Progress in Human Geography 30 (4): 469-486.

Rose-Redwood, Reuben. 2008. "Indexing the Great Ledger of the Community: Urban House Numbering, City Directories, and the Production of Spatial Legibility“. Journal of Historical Geography 34: 286-310.

Rose-Redwood, Reuben. 2012. "With Numbers in Place: Security, Territory, and the Production of Calculable Space". Annals of the Association of American Geographers 102 (2): 295-319.

Rose-Redwood, Rose, Alderman, Derek, and Maoz Azaryahu. 2010. "Geographies of Toponymic Inscription: New Directions in Critical Place-name Studies". Progress in Human Geography 34 (4): 453-470.

Rusu, Mihai Stelian. 2012. “Multi-Paradigmaticity, Scattered Cumulativity, Multi-Localized Ignorance: The Tumultuous Condition of Sociological Knowledge". Revista de Cercetare si Interventie Sociala 39: 187-203.

Rusu, Mihai Stelian. 2019a. "Shifting Urban Namescapes: Street Name Politics and Toponymic Change in a Romanian(ised) City" . Journal of Historical Geography 65: 48-58.

Rusu, Mihai Stelian. 2019b. "Mapping the Political Toponymy of Educational Namescapes: A Quantitative Analysis of Romanian School Names". Political Geography 72: 87-98.

Rusu, Mihai Stelian. 2020a. "Political Patterning of Urban Namescapes and Post-socialist Toponymic Change: A Quantitative Analysis of Three Romanian Cities". Cities 103: 102773.

Rusu, Mihai Stelian. 2020b. "Gendering Urban Namescapes: The Gender Politics of Street Names in an Eastern European City". Names: A Journal of Onomastics, in press.

Seidman, Steven. 1991. "The End of Sociological Theory: The Postmodern Hope“. Sociological Theory 9 (2): 131-146.

Sibiu. 1947. Planul municipiului Sibiu cuprinzând numirile străzilor, cu indicarea lor pe hartă și adresele importante din oraș. Sibiu: Editura „Reclama Sibiului".

Siddique, Haroon and Clea Skopeliti. 2020. "BLM Protesters Topple Statue of Bristol Slave Trader Edward Colston“. The Guardian, online edition, 7 June 2020, available online at https://www.theguardian.com/uk- 
news/2020/jun/07/blm-protesters-topple-statue-of-bristol-slavetrader-edward-colston.

Simmel, Georg. 2009. Sociology: Inquiries into the Construction of Social Forms. Volume 2. Leiden and Boston, MA: Brill.

Sullivan, Rory. 2020. "Anti-racism Campaigners Rename Glasgow Streets Linked to Slave Trade“. Independent, online edition, 6 June 2020, available online

https://www.independent.co.uk/news/uk/home-news/antiracismcampaigners-renamed-glasgow-streets-slave-trade-a9552616.html.

Tantner, Anton. 2009. "Addressing the Houses: The Introduction of House Numbering in Europe". Histoire \& mesure 24 (2): 7-30.

Tuathail, Gearóid Ó. 1996. Critical Geopolitics: The Politics of Writing Global Space. Minneapolis, MN: University of Minnesota Press.

Vuolteenaho, Jani and Guy Puzey. 2018. " Armed with an Encyclopedia and an Axe': The Socialist and Post-socialist Street Toponymy of East Berlin Revisited through Gramsci". In The Political Life of Urban Streetscapes: Naming, Politics, and Place, edited by Reuben RoseRedwood, Derek Alderman, and Maoz Azaryahu, 74-97. London and New York, NY: Routledge.

Vuolteenaho, Jani and Lawrence D. Berg. (Eds.) 1999. Critical Toponymies: The Contested Politics of Place Naming. Farnham: Ashgate.

Vuolteenaho, Jani. 2012. "Numbering the Streetscape: Mapping the Spatial History of Numerical Street Names in Europe“. Urban History 39 (4): 659-679.

Walkowiak, Justyna B. 2018. “Female Street Namesakes in Selected Polish Cities". Mitteilungen der Osterreichischen Geographischen Gesellschaft, 160: 331-350.

Wallace, Ruth A. and Alison Wolf. 2006. Contemporary Sociological Theory: Expanding the Classical Tradition. London: Pearson.

Wangui Wanjiru, Melissa and Kosuke Matsubara. 2016. “Street Toponymy and the Decolonisation of the Urban Landscape in Post-colonial Nairobi“. Journal of Cultural Geography, DOI: 10.1080/08873631.2016.1203518.

Weber, Max. 1930. The Protestant Ethic and the Spirit of Capitalism. New York, NY: Charles Scribner's Sons.

Weber, Max. 1978. Economy and Society: An Outline of Interpretive Sociology. Berkely, CA: University of California Press.

Wilson, Jeffrey R. 2018 "'To Be, or Not to Be': Shakespeare Against Philosophy". Shakespeare 14 (4): 341-359. 
Wright Mills, Charles. 1959. The Sociological Imagination. Oxford: Oxford University Press.

Yeoh, Brenda S. A. 1992. "Street Names in Colonial Singapore". Geographical Review 82 (3): 313-322.

Yeoh, Brenda S. A. 1996. "Street-Naming and Nation-Building: Toponymic Inscriptions of Nationhood in Singapore“. Area 28 (3): 298-307. 